Newfoundland and Labrador Studies

\title{
Relations between the Basques and the French Administration of Plaisance, 1660-1713
}

\section{Nicolas Landry}

Volume 33, numéro 1, 2018

URI : https://id.erudit.org/iderudit/1055867ar

DOI : https://doi.org/10.7202/1055867ar

Aller au sommaire du numéro

\section{Éditeur(s)}

Faculty of Arts, Memorial University

\section{ISSN}

1719-1726 (imprimé)

1715-1430 (numérique)

Découvrir la revue

\section{Citer cet article}

Landry, N. (2018). Relations between the Basques and the French

Administration of Plaisance, 1660-1713. Newfoundland and Labrador Studies,

33(1). https://doi.org/10.7202/1055867ar d'utilisation que vous pouvez consulter en ligne.

https://apropos.erudit.org/fr/usagers/politique-dutilisation/ 


\section{Relations between the Basques and the French Administration of Plaisance, 1660-1713}

Nicolas Landry

\section{Introduction}

This text explores three aspects that have marked the colonial historiography of Atlantic Canada: the opposition of some French Basques to the control of the French colonial administration; their role in supplying the French colony, including manpower for the resident fishers; and their implication in the defence of Plaisance. The choice of these themes largely reflects parameters that have prevailed in the recent historiography. Recently, Brad Loewen and Miren Egaña Goya recalled the Basques' "fear of losing their customary right to conduct a seasonal fishery in Gaspésie and Chaleur Bay during the seventeenth century, at the hands of France and England, which were consolidating their power in the region." ${ }^{1}$ In agreement with these authors, we consider aspects of the "intersection" of French and Basque activities in Plaisance between 1660 and 1713. ${ }^{2}$

Hilario Casado Alonso has stated that "the sum of research dedicated to the Newfoundland fishery today forms a distinctive chapter in the bibliography of global maritime history." ${ }^{3}$ Beginning in the 1520 s, sailors from the Basque Country in Spain and France joined Portuguese, Norman, and Breton fishers in exploiting the Newfoundland cod stocks. The name Plaisance appears as early as 1547 on a map by Nicolas Vallard of Dieppe, in the form of Isle de Plaziencia. M.J. McCarthy believes that the Plaisance region was likely explored by 1501 by Gaspar and Miguel Cortereal, who followed the south and east shores 
of Newfoundland. In 1504, the region was thus identified by a Portuguese name, Insulae Cortrealis. ${ }^{4}$ Plaisance may be the French version of a name designating the town of Plentzia on the Basque coast near Bilbao, which is a Basque version of the archaic Spanish Placencia. According to McCarthy, the origin of Placentia does not lie in the Basque language, but in Spanish. ${ }^{5}$ In fact, two towns are associated with the name of Placentia in the Basque Country: the port near Bilbao and an inland town in the Deba valley, which also carries the Basque name Soraluze. Linguists have suggested the latter is the origin for Placentia in Newfoundland, a hypothesis that has escaped the attention of most historians. ${ }^{6}$ In this paper we will look primarily at Basques from the ports of Bayonne, Saint-Jean-de-Luz, and Ciboure in the province of Labourd in France, in particular, at their role in the fisheries, trade, and military history of the Newfoundland colony from 1660 to 1713.

\section{The Foundation of the French Colony in Newfoundland 7}

In 1564, the people of Saint-Jean-de-Luz and Biarritz announced to their neighbours in San Sebastián that they intended to fish in Plaisance. ${ }^{8}$ Although only temporary shore facilities were used at this time, more and more ships were coming to these shores. At the end of the sixteenth century, more than 50 Basque cod-fishing ships cast their anchors each summer in this region. ${ }^{9}$ Between 1565 and 1605, many notarial acts signed at Bordeaux gave Plaisance as the captains' destination. ${ }^{10}$ The vessels engaged in this coastal fishery were crewed by 30 to 50 men and could carry between 100 and 200 tons, with some ships as spacious as 400 tons. In 1585, the Marie de Saint-Vincent (100 tons) was one of the ships heading for Plaisance from the Basque province of Labourd (France). ${ }^{11}$ Two-thirds of the vessels leaving for Newfoundland from Bordeaux, between 1550 and 1575, in fact originated from the ports of Labourd, which specialized in the dry fishery and the cod trade. ${ }^{12}$ By 1590, the Placentia Bay fishery expanded into the Gulf of St. Lawrence, giving rise to a series of ports on the west coast of Newfoundland in a south-to-north advance. ${ }^{13}$ 
Beginning about 1600, we find Basques dominating trade in the Gulf of St. Lawrence, including trade with Indigenous peoples. Basques were also present in the Strait of Belle Isle, where they traded with the Inuit. ${ }^{14}$ In the early seventeenth century, in the summer of 1620, we find a Dutch ship at Plaisance among the Basque fishing vessels. ${ }^{15}$ The same year, Samuel de Champlain signalled that at least 11 Basque ships fished "each summer" at Miscou, ${ }^{16}$ an island harbour at the northeast point of present-day New Brunswick.

In terms of permanent colonization, the English were the first to show their colours, settling on Newfoundland's east coast in the 1610s at Cupids. ${ }^{17}$ The Basques affirmed their presence in the summer of 1651 when 16 of their ships fished and dried their catch at Plaisance. ${ }^{18}$ As for the French, their first permanent settlement at Plaisance dates to $1655 .{ }^{19}$ According to James Candow, the nomination of a French governor at Plaisance met the disfavour of Saint-Malo merchants, who feared that the new royal authority would interfere with the long-standing customs of the migratory fishery. Similar debates took place at the same time on the English coast. ${ }^{20}$

Gradually, Plaisance was equipped with infrastructure and personnel to fulfill its colonial mandate - a governor, military and civil officers, a garrison, and fortifications. Founded with a view to protect French fishing rights, colonial Plaisance offered many advantages, including a large sheltered harbour, proximity to inshore fishing banks, and spacious beaches with large, flat cobbles suited for drying fish. From a strategic standpoint, the site was surrounded by cliffs and defensible. The port was located on the sea route to Quebec City, so that transiting French vessels could halt and safely anchor. ${ }^{21}$

\section{French Basque Opposition to French Colonial Control}

Some particular aspects of the Basque presence at Plaisance at this time stand out. Few people of Basque origin settled as residents. While Damien Rouet notes "a few Basques," he found that the majority of the colonists came from Aunis, Saintonge, and the Bordeaux region. 
Like Candow, he underlines "an opposition to the project of a permanent colony among the long-standing users of the region, particularly Basques and Malouins who sought by the means at their disposal to limit the governor's authority." 22 Rouet cites the examples of Jean de Jaldaye and Joannis Hiriard, two Basque merchants whose presence in the colony remained essentially seasonal. ${ }^{23}$

To better understand the place of the Basques in the fisheries of eastern Canada, we need to grasp the complexity of their relation to French colonial policy. Starting at the beginning of the seventeenth century, French Basque traders questioned the legality of the French trade monopolies. They argued that the law of the sea guaranteed their free access to maritime resources, while their historical rights in the region took legal precedence over the French fur trade monopolies. ${ }^{24}$

Basque opposition to the control of colonial authorities, which they saw as excessive, has a long history. Basques repeatedly affirmed their right to fish and trade in the regions where the French proclaimed themselves as masters in the seventeenth century. ${ }^{25}$ Samuel de Champlain witnessed hostilities at Tadoussac in 1608, between one Basque trading vessel and another that had acquired certain privileges. ${ }^{26}$ In the 1620s, agents of the French Compagnie de Caen and the Cent-Associés confronted Basque ships that were trading at Tadoussac, Miscou, and elsewhere in Acadia. ${ }^{27}$ Similar divergences led to tense episodes between French authorities and Basque fishermen between 1623 and 1660, in Chaleur Bay and on Île Saint-Jean (Prince Edward Island). ${ }^{28}$

In the first years of the Plaisance colony, the governor, Thalour de Perron, and his chaplain were assassinated. ${ }^{29}$ His successor, Gaspard de La Poippe, was threatened by a Basque captain who had been beaten up (“fait casser la tête")! ${ }^{30}$ Another incident that would merit further investigation happened about 1662 . We read in a letter from a captain Haristéguy to the minister Colbert that Basque and Breton leaders burned down the fort at Plaisance to reinforce their demand for a sum of money owed to them. ${ }^{31}$ By the end of the 1660s, however, relations between Basques and colonial administrators were generally more cordial. ${ }^{32}$ A French merchant who visited Plaisance in the first half of the 
1670s criticized the behaviour of certain fishing captains and merchants, especially Bretons and Basques: "they would not participate in affairs relating to the colony that were outside of their fishery, such as refusing to join Governor La Poippe in a privateering venture against Spanish ships moored in nearby harbours" in the summer of $1674 .{ }^{33}$

In the history of Plaisance, an episode cited in the historiography to illustrate Basque resistance to royal authority seems to have happened in August 1690. Before getting into the event itself, it is worthwhile to consider its historical context. On one hand, the Basques often showed great solidarity in the face of French colonial authority, as most crew members came from the same region. ${ }^{34}$ On the other hand, the origin in Spain of many Basque fishermen may have been problematic for French authorities. French governors at Plaisance sometimes appeared reluctant to recognize that the Basques — as well as the Mi'kmaq had been serious in their contribution to the colony's defence and to raiding expeditions against the English Shore. Indeed, if the colony had been able to ward off the English attacks of 1692 and 1693, it was above all because crews from European vessels, including Basques, helped in the defence..$^{35}$ As Laurier Turgeon has remarked, the War of the League of Augsburg (Nine Years' War, 1688-97) and the War of the Spanish Succession (1702-13) did not stop the Basques from outfitting "ships for Newfoundland and Greenland," which slipped through the lines of English patrols and corsairs. ${ }^{36}$

With this as background, we can come back to the so-called "sedition" of August 1690, when French authorities considered that the French Basque ship captains and their crews took advantage of a depleted garrison after the English had attacked and pillaged Plaisance in February of the same year. The Basques, who had come to the colony's aid at a critical moment, may have considered that the governor was not in a position to dictate his will. According to the officer, Pastour de Costebelle, the Basques openly declared that they did not recognize any authority in Newfoundland, and his minutes are our only way of reconstituting events. ${ }^{37}$ Six Basque captains were accused of "grandes violences" against Costebelle and the governor, Antoine Parat. 
Four were from Saint-Jean-de-Luz and one was from Bayonne. Those named were Jean de Heribour, Bernard Darnadel, Martin Hiribaritz, and Auger Lombara the younger. Two confrontations occurred.

First, the ship's master, Jean de Heribour, attacked a soldier and, in a subsequent standoff, another master, Bernard Darnadel, was slightly injured on the head by a flying stone. A third quarrel broke out in the guardhouse between the wife of a resident and some Basque sailors. It appears that the sailors had insulted the woman's daughter, and her son then injured one of the crewmen. Shortly afterwards, at Darnadel's instigation, the crews of several ships converged on the scene, armed with muskets, axes, and knives. As many as 300 armed Basques confronted the garrison and the resident population. Ultimately, it took the intervention of Reverend Father Joseph Denys to restore calm. Our sources do not indicate the outcome of these events; for example, we do not know whether the leaders of the "sedition" were judged or sentenced. ${ }^{38}$ Whatever the case, the event seems to have been taken in stride by other Basque captains. In 1692, the fishing captains of Gipuzkoa declared to the Spanish Navy that French authorities in Newfoundland had never troubled them in the conduct of their fishery. ${ }^{39}$ A telling incident followed the English raid of 1691, which was disastrous for Plaisance. That spring, when the Basques arrived in Plaisance for the fishing season, the commander of the colony, Antoine Parat, was determined to abandon his post. He tried to board a fishing vessel but the Basques refused his request for passage. Their unwillingness to aid his desertion meant that Parat was obliged to leave the colony in September by way of Saint-Pierre, where he found passage on a Saint-Malo ship instead. ${ }^{40}$

The second example used to illustrate the desire for self-sufficiency of Basque captains and crews occurred in 1697, during the War of the League of Augsburg. In a memorandum addressed to the commissioner of the Marine in Bayonne, Florent de Argoud questioned a royal order for fishing ships to gather in one place at the end of the season and sail in convoy to France. The same year, the King had also ordered all ships bound for Newfoundland to fish only at Plaisance. 
Argoud presented the arguments against the directive. First, wind conditions could force ships to fish elsewhere. Second, in allowing captains to fish where they pleased in Newfoundland, they would be less inclined to go instead to Île Percée, Gaspé, or farther north in the Gulf of St. Lawrence where cod abounded until September. According to Argoud, no ship would go to Newfoundland if it could fish only at Plaisance, because of the risk of returning with a partial cargo. ${ }^{41}$ The French officer Bacqueville de la Potherie considered that the Basques dominated the Plaisance fishery at the end of the seventeenth century, adding that "the Basques make large profits because they carry their cod to Portugal, and in time of peace to Spain." In 1696 at Plaisance, the Basques operated 115 chaloupes, compared to 94 for all the resident fishers and military officers. ${ }^{42}$

Another example of Basque crews resisting a royal order to fish only at Plaisance is seen in the 1708 mutiny of L'Espérance. The ship sailed from Saint-Jean-de-Luz in the midst of the War of the Spanish Succession. Commanded by Auger Dolobarat with a crew of 80 men, the ship was directed by its outfitter, François Duges, to fish in Plaisance and in no other place. However, having gained the Grand Bank of Newfoundland on 5 May, the crew insisted on fishing at Chapeau Rouge or in Saint Lawrence Bay, and not at Plaisance. The official correspondence refers to a "revolt" led by Joannis Chapellan, who apparently muscled Captain Dolobarat. Finally, the ship went to fish in St. Mary's Bay, where the English briefly held it as a war prize. When the ship finally got to Plaisance, the colonial authorities arrested several of the "mutineers." 3

During the War of the Spanish Succession, marked by French and English privateering in Newfoundland, the Basque fleet returning from Plaisance fell victim to an English attack in 1712. On 10 October, the 34-gun frigate Milford captured three of the biggest fishing ships. Perhaps out of habit, the Plaisance administrators sought someone to blame and turned on the "most obstinate of the Basque captains" who had "influenced" the others despite the orders of de Costebelle. The governor suggested that the King should force the "disobedient" 
Basques to absorb the cost of repatriating the prisoners released by the English. ${ }^{44}$ It should be mentioned that this was not the first time the governor had faced a similar situation, as in 1707 he had dealt with the English capture of two ships from Saint-Jean-de-Luz at Saint-Pierreet-Miquelon. On that occasion as well, he blamed "the obstinacy of the Basques who do not follow orders," that is, they failed to desist from going to trade where they were exposed to danger. ${ }^{45}$

Despite such tensions with the colonial administration, the Basques were by no means unwilling to lend a hand in the colony's defence against the English. Thus, French administrators credited the Basques for helping to push back English assaults on Plaisance, as happened twice during the Augsburg and Spanish Succession wars. On the first occasion, on 14 September 1692 when the English laid siege to five ships, the governor, Monbeton de Brouillan, convened the captains of vessels that were set to leave for France. Among the captains were the Basques Auger Dolobarat, Michel Béraud de Monségur, Jean Hiriart, and Baraguet. They were asked to help in the defence of Plaisance by placing their ships in a line across the entrance to the ba$\sin$. The official correspondence following this battle mentions that the Basque captains distinguished themselves by their bravery in the face of 2,000 English rounds that smashed several houses in Fort Louis. The same captains lent 120 men and officers who handled themselves "very favourably" in manning the French batteries. A letter from Antoine-Charles de Gramont to the Marine minister, Louis Phélypeaux de Pontchartrain, confirms that Plaisance was victorious in thwarting the English attack thanks in part to the help of the Basques. ${ }^{46}$ It was on this occasion that the Gascon author and traveller, Baron de La Hontan, led a troop of 60 Basques in the defence of Plaisance. ${ }^{47}$

Later in the war, some Basques joined French authorities in their offensives against the English Shore. In March 1696, we find de Brouillan or one of his representatives in Bordeaux arming a corvette for the upcoming campaign in Newfoundland. He nonetheless had trouble recruiting the 25 Basque sailors that the King had granted him. ${ }^{48}$ In the following war, however, Basques volunteered for land 
expeditions against the English Shore. In 1705, the merchant Jean Daresche of Plaisance entered into a corsair-type agreement with three Basque associates to raid the English Shore. Daresche agreed to supply food, guns, and ammunition. If there would be no prizes, the Basque associates would return the weapons but were not required to reimburse the food and ammunition, which could be used for hunting to provide sustenance during the expedition. ${ }^{49}$ It is difficult to say if this kind of agreement was frequent and we are inclined to think that many were settled by a simple handshake.

\section{Basques in the Colony's Supply and Trade}

Analysis of the colony's administrative correspondence between 1660 and 1713 suggests that French ships calling at Plaisance tended to fall into three general categories. Malouin ships came with merchandise for the colony, Basque ships came to fish, while Nantes and Rochelais ships both traded and fished. Other sources, however, show more complex aspects of French Basque navigation to Plaisance. Certain French Basque captains are repeatedly named in a large number of documents written in Plaisance, by colonial administrators or others, for all kind of financial transactions. This was not an optional practice because the Greffe was a central registry for agreements involving the exchange of money, trade voyages, and the like. Prominent roles seem to have been played by Marsans de Salaberry, Pierre Dolobarat, Joachim de Harnader, Martin Detcheverry, Jean de Jaldaye, Martin de Sopitte, and André Daresche. ${ }^{50}$

French Basque and French merchants doing business in Plaisance were often criticized by colonial officials for their role in supplying the colony with goods and manpower. Amanda Crompton has suggested that this criticism was in part motivated by the fact that colonial authorities were themselves involved in fishing and trading. Thus the European merchants, whether they were Basques or not, were commercial competitors. ${ }^{51}$ In a parallel manner, officials in Quebec and Acadia often levelled criticism at the Compagnie de 
la pêche sédentaire d'Acadie, under the pretext that the company's directors were Huguenots. ${ }^{52}$ Did the desire to undercut a competitor underlie both criticisms? Indeed, prudence is required with respect to the traditional historiographical stance that resident populations were victims of oppressive monopolies that allowed no alternative to their commercial control..$^{53}$

To supply the colony's material needs, the King not only outfitted royal vessels but also contracted merchants in French and French Basque ports. In the fall of 1692, French Basque merchants offered to supply Plaisance, on the condition that they would be favoured over their competitors from Nantes. The Marine minister was not particularly warm to their proposal, reminding them of previous abuses in their trade with the Plaisance inhabitants. This kind of criticism appears continually in the colony's official correspondence; in general, residents found prices too high and deplored the scarcity and poor quality of certain goods. ${ }^{54}$ These complaints did not prevent Pontchartrain from contracting a group of merchants from Bayonne and Saint-Jean-de-Luz to supply the colony. ${ }^{55}$ In 1694, Basque merchants again obtained access to the Plaisance market. On this occasion, the King agreed to provide two flutes (cargo-carrying ships) and a 30gun frigate, along with 130 Basque sailors, to a consortium of 10 merchants from Bayonne and Saint-Jean-de-Luz. As well, the Basques did not wish to supply clothes and foodstuffs, and offered 25,000 livres to the King, who would provide these goods. ${ }^{56}$ The same year, Governor de Brouillan considered asking the Basques and Nantais to propose separate "treaties" to supply Plaisance, and thus bring them into competition with each other. ${ }^{57}$ Moreover, such supply contracts were inseparable from fishing interests. For example, the merchants could fish in Saint-Pierre-et-Miquelon, as well as supply the residents and soldiers who were stationed there. Referring to one such "treaty" with an outfitter from Nantes named Danguy, the anonymous writer of a letter, likely addressed to the minister of the Marine, saw no problem in allowing Danguy to fish from the island of Saint-Pierre. However, Danguy should not take back the gear and chaloupes he had advanced 
to the resident fishermen, who otherwise would be unable to subsist and pay their debts. ${ }^{58}$

The Plaisance residents needed not only supplies to prosecute the fishery, but also manpower in the form of engagés. In the fall of 1688, the naval officer Louis Pastour de Costebelle sent a list to Bayonne of the number of fishermen and chaloupe masters required by resident fishermen for the 1689 season..$^{59}$ The colonial administrators considered that even the war (of Augsburg) should not prevent the commissioners in Bayonne and Saint-Jean-de-Luz from sending engagés to Plaisance. Without this manpower, resident fishermen might leave the colony and concede the whole fishery to merchants from the Basque ports. ${ }^{60}$ Colonial archives contain many contracts for engagés and countless historians have described the fishermen's working conditions. We may take the example of 10 men who were hired by a Nantes merchant in 1694 . The engagés, all from the French Basque Country, would receive a third of the proceeds of the fish that the merchant had an option to buy. Their bonuses included an advance of 180 livres for the chaloupe masters, 70 livres for the boatswains (bossoins) and stevedores (arrimeurs), and 60 livres for the shoremen (graviers). ${ }^{61}$

Often, we read complaints that European ships did not respect their agreements and did not bring the requested number of engagés for the resident outfitters. True, the number and role of the engagés varied from year to year. ${ }^{62}$ For example, according to colonial officials, none of the men hired by notarized contract at Plaisance at the end of the 1699 season showed up for work in 1700, thus depriving six resident fishermen of engagés to work their rooms. The situation brought sharp criticism from the commander, Joseph de Monic, who seems to imply that Basque suppliers favoured some residents by bringing them more engagés, and appears more conciliatory towards the suppliers from Saint-Malo and Nantes. ${ }^{63}$ In the same vein, in 1705 Governor de Subercase reiterated the need to show the Basques that the King wished to encourage the resident fishery and that the garrison's duty was not only to protect the Basque fishery. To stabilize the manpower 
situation, he wished to set a minimum contribution of 80 engagés per year for the resident fishery. ${ }^{64}$

Basque merchants were thus heavily committed to the Plaisance trade, and we may look at some of the judicial instruments that framed their activities. Like their competitors, they turned to the notary to register their commercial transactions and hiring contracts. A procuration (power of attorney) enabled a merchant to name a representative who would be responsible for his affairs in his absence. An example is the general procuration given to Jean Peris Harnader, a Ciboure merchant who was asked by the Plaisance merchants Joannis Daccarrette ${ }^{65}$ and Georges de Lasson to act in their name. In the instructions and memoranda that the two merchants sent to Harnader, they empowered him to manage their affairs, negotiate for all kinds of merchandise, and defend their legal rights. ${ }^{66}$

Another type of notarized act, the quittance, ${ }^{67}$ served as a credit instrument. An example from the fall of 1705 illustrates the spirit of this type of act. It involves Joannis Goyheche of Plaisance, who reimbursed 140 livres to de Lasson the younger. Goyheche's father owed this amount to a Bayonne burgess and merchant that de Lasson accepted to pay. ${ }^{68}$ If agreements did not work out as hoped, one could send a sommation (summons) that carried the legal obligation to reimburse an unpaid debt. Such was the case in 1680 when the master of the Sainte-Thérèse of Bordeaux, Pierre Sugnet, left for Newfoundland with a cargo of foodstuffs. His ship belonged to the burgess Antoine Lamarque and was equipped for the dry fishery. On reaching Plaisance, Sugnet was accosted by Auger Dolobarat of Saint-Jean-deLuz, who summoned him to pay for a charroi (a sailboat for coastal transport) that he had borrowed in Newfoundland in 1679 and subsequently lent to Jacques Thomas, commander of the Saint-Domingue, also of Bordeaux. ${ }^{69}$ 


\section{The Onset of an Inexorable Decline?}

In a memorandum sent to the French Court in March 1710, the Basques claimed to be the veritable discoverers of Newfoundland and to have harvested the resources of the Gulf of St. Lawrence well before the English settled in the New World. ${ }^{70}$ Certainly, the Basques had a solid knowledge of the geography of eastern Canada and their own history in the region's economy. The memorandum sought to convince the French authorities to stay in Plaisance, rather than move to the new capital on Îsle Royale (Cape Breton). ${ }^{71}$ The merchants of Saint-Jean-de-Luz and Ciboure argued against the move in 1716, reminding the Conseil de la Marine of their previous letter to Pontchartrain that outlined the disadvantages of ceding Plaisance to the English. ${ }^{72}$ Loewen and Delmas agree with Pierre Nadon in saying that the Basques who followed the French to Îsle Royale did so with little enthusiasm. According to these authors, the fishing rooms were too crowded and the catches were inferior to those of Newfoundland. ${ }^{73}$ As late as 1727 , the outfitter Beauvais Lefer insisted on the need to retake Plaisance. ${ }^{74}$

\section{Conclusion}

This brief historical incursion into the Basque presence at Plaisance allows us to summarize a few findings. It seems that the Basques did not particularly favour the establishment of French authorities in Newfoundland - at least, not if it restricted their fishing activities. Like other migratory fishermen, including the English on the east coast, the Basques functioned within a customary framework that all European ships respected. Each captain had an interest in showing discernment if he wanted to maintain his access to the fish resource and the right to process his catch on shore. The Basques' limited interest for settling as resident fishermen at Plaisance is confirmed by the colony's censuses. For most Basques, there was no reason to reside in Plaisance in order to fish, trade, or even take part in the colony's defence. 
On the other hand, we see a measure of fluidity in the Basques' disposition towards the Plaisance colony. While they reacted against colonial power in the 1690 "sedition," Basques defended the colony against the English attack in 1692. We may ask whether their acts of opposition to colonial authority were more the exception than the rule. Their commercial relations with the resident fishers and their role as manpower suppliers suggest that they were, in general, fairly well integrated into the colony. We may ask whether the Basques were too easily labelled as obstinate and poorly inclined to follow orders; after all, similar names were levelled at the Acadians, who were called Republicans. ${ }^{75}$ While the Plaisance administrators, at least in their official correspondence, often represented the Basques as a source of disorder and discontent, on occasion they also recognized their contribution to the colony.

\section{Appendix I: A Window on Maritime Trade between Bayonne and Plaisance in the Seventeenth Century}

Complementing this brief look at the Basque presence at Plaisance, we have explored data from the website Nouvelle-France (Archives de la Nouvelle-France), put online through a Franco-Canadian joint initiative. ${ }^{76}$ The data were compiled from registers of ships' passports and declarations in the Fonds de l'Amirauté de Guyenne (Archives départementales de la Gironde). The data provide some insights into navigation between this region of France and Plaisance between 1684 and 1700 . For each ship, we find information on the owners, captains, garrisons, the duration of the voyages in each direction, damages, cargos, crews, etc. To lighten the text, we have omitted the archival reference for each file. ${ }^{77}$

Our sample includes 38 declarations, of which not all contain the same types of information. The years 1696 and 1699 are the busiest, with five and nine declarations respectively. Out of the 30 declarations that specify a home port, 13 name Bordeaux and four give Saint-Malo. For the 38 declarations, the ships averaged 100 tons in capacity. The 
Ville de Bayonne was the largest at 300 tons while the Jeanne-Marie of La Rochelle was the smallest at only 35 tons. As for the outbound cargos, not surprisingly they include mostly foodstuffs, but also diverse merchandise, wine, eau-de-vie, and stone for the Plaisance fortifications. ${ }^{78}$ Just as naturally, dry and wet cod dominate the return cargos. In 12 cases where the crews are enumerated, the average is $21 \mathrm{men}$. We find only five mentions of passengers, for an average of nine per ship. Six vessels were equipped with cannon, with 13 pieces being the average. As for the duration of the Atlantic round trip, in 19 observable cases the average is 40 days.

Among the ships returning from Plaisance with fish, we find the Prince de Granville with 150,000 dry and 300 wet cod in 1698; the Jeanne-Marie of La Rochelle with 40,000 dry cod in 1699; and the Saint-Pierre of Saint-Malo, the same year, with 80,000 dry cod. The Hardi of Saint-Jean-de-Luz declared the same quantity in September of the same year. Also the same month, the Vierge de Pontrieux of Saint-Malo declared 50,000 dry cod but its captain feared that this precious cargo had been soaked during bad weather on the Grand Bank of Newfoundland. He was not alone in complaining, since the Dragon of Bordeaux, arriving on 6 December with 160,000 cod on board, had also taken on water. It had sailed through a storm that lasted eight days and forced the crew to jettison the main mast, the mizzen, some rigging, 12 disassembled barriques, three tons of wood, 12 planks, 12 small masts, and a pierrier (a small cannon). In all, four ships in our sample declared "soaked" (mouillé) cod, if we include the Marie-Françoise and the Diligent, which convoyed under the command of Monsieur de Saint-Claire in December 1694.

On the Dominique of Bordeaux, we find a crew of 18 men including six Basques. On the Sauvage, also of Bordeaux, the 17 crewmen were all of "Basque nationality" who had "served in the cod fishery" in the summer of 1688. In September 1689, the Ville de Matignon (150 tons) had 56 crewmen but returned without the sailor Lespine Frisler, from Sainte-Blanche parish near Granville. The lieutenant at Plaisance had sent him to Quebec for "having injured a resident" of 
Newfoundland. During the War of the League of Augsburg, many fishing and trading vessels had commissions or lettres de marque authorizing them as corsairs. We see the Saint-François of Ciboure claiming a prize on the banks of Newfoundland with the help of five ships from Nantes and Saint-Jean-de-Luz. Unfortunately, a Dutch vessel from Flushing subsequently took the prize away.

\section{Notes}

1 Brad Loewen and Miren Egaña Goya, "Le routier de Piarres Detcherverry, 1677. Un aperçu de la présence basque dans la baie des Chaleurs au XVIIe siècle," Revue d'histoire de l'Amérique française 68, 1/2 (2014): 128.

2 Researchers interested in the history of the French fisheries will be happy to discover the new book by Mario Mimeault, La pêche à la morue en Nouvelle-France (Québec: Septentrion, 2017). It shows that the fishery, to the same extent as the fur trade, was essential to the colonial economy of Laurentian and Gaspesian New France.

3 Hilario Casado Alonso, "La pêche à Terre-Neuve et le commerce international: deux activités complémentaires au XVIe siècle," Annales de Bretagne et des Pays de l'Ouest 120-2 (2013): 111.

4 M.J. McCarthy, "A History of Plaisance and Placentia, 1501-1970" (St. John's: Government of Newfoundland and Labrador, Unpublished manuscript, 1973), 43. See also Selma Huxley Barkham, The Basque Coast of Nerwfoundland (Plum Point, NL: Great Northern Peninsula Development Corporation, 1989).

5 Details provided by the historian Jim Candow of Parks Canada, Halifax, in 2008, at the time of my work leading to the publication of Nicolas Landry, Plaisance (Terre-Neuve) 1650-1713. Une colonie française en Amérique (Québec: Septentrion, 2008). On the subject of Basque place names in Newfoundland, see also Christian Weyers, "Basque Traces in the Toponymy of Newfoundland and Various Coasts of Atlantic Canada," Proceedings of the 23rd International Congress of Onomastic Sciences, Toronto, York University, 2009.

6 See also the article by Miren Egaña Goya in this issue. Thanks to Brad Loewen for making the link. 
7 This paragraph comes mostly from Landry, Plaisance Terre-Neuve 1650-1713, 15-16.

8 McCarthy, "History of Plaisance and Placentia," 43.

9 René Bélanger, Les Basques dans l'estuaire du Saint-Laurent, 1535-1635 (Montréal: Presses de l'Université du Québec, 1971), 57.

10 Miren Egaña Goya reports that the oldest reference to a Basque burial in Plaisance dates to 1563. "A Permanent Place in Newfoundland:

Seventeenth-Century Basque Tombstones in Placentia” (in this issue).

11 Laurier Turgeon, "Bordeaux and the Newfoundland Trade during the Sixteenth Century," International Journal of Maritime History 9, 2 (Dec. 1997): 10, 16.

12 Laurier Turgeon, "Pour redécouvrir notre $16^{\mathrm{e}}$ siècle: les pêches à Terre-Neuve d'après les archives notariales de Bordeaux," Revue d'histoire de l'Amérique française 39, 4 (printemps 1986): 532. Cited in Olaf U. Janzen, "The Logic of English Saltcod: An Historiographical Revision," The Northern Mariner/le marin du nord 23, 2 (Apr. 2013): 127.

13 Gaëlle Dieulefet, "The Isle aux Morts Shipwreck: A Basque Ship from Saint-Jean-de-Luz in the Seventeenth Century" (in this issue). The same author states that, at the end of the seventeenth century, the San Sebastian Admiralty named 16 Basque fishing ports around Placentia Bay and four on the west coast, citing Brad Loewen and Vincent Delmas, "The Basques in the Gulf of Saint Lawrence and Adjacent Shores," Canadian Journal of Archaeology/Journal Canadien d'archéologie 36 (2012): 363.

14 Peter E. Pope, "Bretons, Basques, and Inuit in Labrador and Northern Newfoundland: The Control of Maritime Resources in the 16th and 17th Centuries," Études/Inuit/Studies 39, 1 (2015): 19. With time, tensions also appeared between these two groups.

15 Peter Pope, "Adventurers in Sack Trade: London Merchants in the Canada and Newfoundland Trades, 1627-1648," The Northern Mariner/le Marin du nord 6, 1 (Jan. 1996): 3.

16 Loewen and Egaña Goya, "Le routier," 126.

17 Gilles Havard and Cécile Vidal, Histoire de l'Amérique française (Paris: Flammarion, 2003), 67-68. Ferryland was founded in 1621 at the initiative of Sir George Calvert, who would become Lord Baltimore. 
In 1638, Sir David and Lady Sara Kirke arrived, accompanied by a hundred colonists. The establishment suffered a Dutch attack in 1673. Barry C. Gaulton and Tania Manuel Casimiro, "Custom-made Ceramics, Trans-Atlantic Business Partnerships and Entrepreneurial Spirit in Early Modern Newfoundland: An Examination of the SK Vessels from Ferryland," International Journal of Historical Archaeology 19 (2015): 2-3.

Charles de La Morandière, Histoire de la pêche française de la morue dans l'Amérique septentrionale des origines à 1789 (Paris: G.P. Maisonneuve et Larose, 1962), Tome I, 409. According to Damien Rouet, the decision to found a colony at this place was made "with the input of Malouins and Basques." “Territoires, identité et colonisation: l'exemple de Plaisance," in Maurice Basque and Jacques-Paul Couturier, eds., Les Territoires de l'identité. Perspectives acadiennes et françaises, XVIIe-XXe siècles (Moncton, NB: Chaire d'études acadiennes, Université de Moncton, Collection Mouvange, 2005), 192.

19 About 1650, there were again about 20 cod-fishing ships from Gipuzkoa in Placentia Bay, where their numbers increased with each passing year. Laurier Turgeon, "Pêches basques du Labourd en Atlantique nord (XVIe-XVIIIe siècle): ports, routes et traffics," Itsas Memoria. Revista de Estudios Maritimos del Pais Vasco 3 (2000): 174.

20 James E. Candow, "An Overview of the Northwest Atlantic Fisheries, 1502-1904," The Sea, 167. Thanks to the anonymous reader who remarked: "Indeed, the issue of conflict between advocates for colonization and for the migratory fishery has been a central point of focus in English Newfoundland historiography since the late 18th century. Peter Pope, Fish into Wine, pp. 203-204.”

21 Amanda Crompton, "Confronting Marginality in the North Atlantic: Archaeological and Historical Perspectives from the French Colony of Plaisance, Newfoundland," Historical Archaeology 49, 3 (2015): 56.

22 Rouet, "Territoires, identité et colonisation," 194.

23 Ibid., 199. This may be the same Hiriart whose name appears on a tombstone at Placentia, as evoked by Miren Egaña Goya elsewhere in this volume.

24 Catherine Losier, Miren Egaña Goya, and Brad Loewen, "Archaeological Diversity in the French Atlantic: The Seventeenth-Century 
Basque Fisheries in Southern Newfoundland and Saint-Pierre-etMiquelon" (in this issue).

25 René Bélanger, Les Basques dans l'estuaire du Saint-Laurent (Montréal: Presses de l'Université du Québec, 1971). Cited in Loewen and Egaña Goya, "Le routier", 133.

26 Dominique Lalande, "Archaeological Excavations at Bon-Désir: Basque Presence in the St. Lawrence Estuary," Northeast Historical Archaeology 18, 1 (1989): 17.

27 Brad Loewen and Vincent Delmas, "The Basques in the Gulf of St. Lawrence and Adjacent Shores," Canadian Journal of Archaeology/ Journal Canadien d'Archéologie 36 (2012): 373.

28 Loewen and Egaña Goya, "Le routier," 144. Mario Mimeault mentions another violent incident that took place in the eighteenth century at Grande-Rivière. "Du golfe Saint-Laurent aux côtes de Bretagne et de Normandie (1713-1760)," Revue d'bistoire de l'Amérique française 67, 1 (2013): 16.

29 René Beaudry, "Du Perron, Thalour," Dictionnaire biographique du Canada, vol. I. Consulted 3 Nov. 2017. Beaudry does not specify whether the guilty party was Basque or not. http://www.biographie.ca/ fr/bio/du_perron_thalour_1F.html.

30 Antoine Parat to the Minister, 9 July 1688. Library and Archives Canada (henceforth LAC), MG1-C11C, vol. 1, f. 89-94. In 1688, the same Parat received the order to map the coasts of Newfoundland. The following year he received a map traced by the Basque Pierre Detcheverry. Michel Mollat du Jourdin and Monique de La Roncière, Les Portulans, cartes marines du XIIIe au XVe siècle (Fribourg, Switzerland: Office du Livre, 1984), carte 97. Cited in McCarthy, "History of Plaisance and Placentia," 54.

31 Saint-Jean-de-Luz, letter from Captain Haristéguy to Colbert, 6 Oct. 1662, LAC, MG7, Série IA-6, vol. 112, pp. 109-10, reel C-12867.

32 Loewen and Egaña Goya, "Le routier," 142-43.

33 Amanda Crompton, "The Travels of Henri Brunet, a Migrant Merchant in Seventeenth-Century French Newfoundland," in John Willis, ed., Tu sais mon vieux Jean-Pierre: Essays on the Archaeology and History of New France and Canadian Culture in Honour of Jean-Pierre 
Chrestien (Gatineau, Que.: Canadian Museum of History Mercury Series, 2017), 122.

34 Mimeault, "Du golfe Saint-Laurent," 20.

35 Mémoire sur Plaisance, 1694, LAC, MG1-C11C, vol. 2, f. 218-19.

36 Turgeon, "Pêches basques du Labourd," 175.

37 Louis Pastour de Costebelle to the Minister, 30 Aug. 1690, LAC, MG1-C11C, vol. 1, f. 148-49. From the same to Secrétaire d'État à la Marine, 20 Aug. 1690, LAC, MG1-F3, Collection Moreau de Saint-Méry, f. 297.

38 Landry, Plaisance (Terre-Neuve) 1650-1713, 331-32.

39 Loewen and Egaña Goya, "Le routier," 142.

40 Thanks to an anonymous reader for this information. LAC, MG1C11C, vol. 1, fol. 185-86v.

41 Mémoire sur la pêche de la morue à Plaisance, par monsieur Argoud à Bayonne, 3 Feb. 1697, LAC, MG1-C11C, vol. 2, f. 126-27.

42 Caroline Ménard, "Un mémoire écrit par Bacqueville de la Potherie," Nerwfoundland and Labrador Studies 21, 2 (2006): 331.

43 To Monsieur François Durand de La Garenne, sub-delegate to Monsieur l'Intendant and Lieutenant de l'Amirauté at Plaisance, 31 Aug. 1708, LAC, MG1-G3, f. 99.

44 Philippe Pastour de Costebelle to the Minister, 24 Oct. 1712, LAC, MG1-C11C, vol. 7, f. 168.

45 Philippe Pastour de Costebelle to the Minister, 14 Sept. 1707, LAC, MG1-C11C, vol. 5, f. 107-09. Cited in Nicolas Landry, "La Guerre de Succession d'Espagne à Terre-Neuve (1702-1713)," Société historique acadienne. Les Cahiers 41, 3 (Sept. 2010): 147.

46 Nicolas Landry, "La Guerre de la Ligue d'Augsbourg à Terre-Neuve, 1689-1697," Société historique acadienne. Les Cabiers 41, 2 (June 2010): $82,84-85$.

47 Well before this event, Baron de La Hontan tried to recruit 50 Basque sailors because, according to him, "ils sont connus comme étant les plus adroits et les plus habiles mariniers qui soient au monde." Nouveaux Voyages de Mr Le Baron de La Hontan dans l'Amérique septentrionale, 239,242 . The original version of this work is available at https:// archive.org/stream/nouveauxvoyagesd03laho\#page/n5/mode/2up. 
One anonymous reader of this paper is of the opinion that La Hontan was not always accurate in his writing.

48 Jean-François Monbeton de Brouillan to the Minister, 12 Feb. 1696, LAC, MG1-C11C, vol. 2, f. 107-08.

49 Accord entre Jean Daracq (ou Daresche) et trois Basques pour une course sur les ennemis, 9 July 1705, LAC, MG1-G3, 7/175, pièce 23, and 2 Sept. 1705, G3, pièce 39. These pieces are cited in Nicolas Landry, "Les activités de course dans un port colonial français: Plaisance, Terre-Neuve, durant la guerre de Succession d'Espagne, 1702-1713," Acadiensis 34, 1 (2004): 65.

50 Landry, Plaisance (Terre-Neuve) 1650-1713, 66, 78-79.

51 Crompton, "Confronting Marginality," 63.

52 Nicolas Landry, "La Compagnie de la pêche sédentaire en Acadie, 1682-1708," Port Acadie. Revue interdisciplinaire en études acadiennes 22-23 (automne 2012/printemps 2013): 9-42.

53 Crompton, "Confronting Marginality," 68.

54 Lettre de Bazin de Bezons to the Minister, 25 Nov. 1692, LAC, MG2-B3, vol. 73, f. 267-70v.

55 On this matter, see James Pritchard, "Le Profit et la Gloire: The French Navy's Alliance with Private Enterprise in the Defence of Newfoundland, 1691-1697," Newfoundland Studies 15, 2 (1999): 165-66.

56 Castines to the Minister, 24 Oct. 1694, LAC, MG2-B3, vol. 82, f. 245-49v.

57 Extract from the letters of Jacques-François de Monbeton de Brouillan, 1694, LAC, MG1-C11C, vol. 2, f. 22-27.

58 Pièce relative au Traité qui permet aux Basques d'aller pêcher aux îles Saint-Pierre-et-Miquelon, 1694, LAC, MG1-C11C, vol. 2, f. 9-9v. An important detail of this treaty is that it does not prevent ships from other ports in France from fishing at Plaisance.

59 Louis Pastour de Costebelle to the Minister, 3 Sept. 1688, LAC, MG1-C11C, vol. 1, f. 101-04.

60 Philippe Pastour de Costebelle to the Minister, 1691, LAC, MG1C11C, vol. 1, f. 136-136v. Mémoire sur les envois à faire à Plaisance, 1694, LAC, MG1-C11C, vol. 2, f. 7-8.

61 Engagement auprès du sieur D’Anguy, 23 Feb. 1694, La Rochelle, LAC, MG6-A2, 3E-Étude Menon: Rivière et Soullard, vol. 1810, f. 
23. Cited in Nicolas Landry, "Échanges entre une colonie et un port métropolitain: Plaisance (Terre-Neuve) et La Rochelle, 1688-1713," in Mickaël Augeron, Jacques Péret, and Thierry Sauzeau, eds., Le Golfe du Saint-Laurent et le Centre-Ouest français. Histoire d'une relation singulière (XVIIe-XXe siècle) (Rennes: Presses universitaires de Rennes, 2010), 107.

62 On the subject of Basque sailors coming to Plaisance as "passengers," see the Mémoire du Commissaire La Boulaye, 2 May 1688, LAC, MG2-B3, reel C-10224. The sailors came to Plaisance on their own account or paid by residents.

63 Landry, Plaisance (Terre-Neuve) 1650-1713, 91.

64 Daniel Auger de Subercase to the Minister, 22 Oct. 1705, LAC, MG1-C11C, vol. 5, f. 195-226.

65 At Saint-Jean-de-Luz in the sixteenth century there was a Maison Daguerette formed by a group of merchants represented by a Basque agent in Bordeaux. Loewen and Delmas, "The Basques in the Gulf," 369.

66 Procuration by Georges de Lasson le jeune and Johannis Daccarrette for Jean Peris Harnader, 11 Aug. 1705, LAC, MG1-G3, 7/175, pièce 30 .

67 A quittance is a notarized act in which a creditor attests that the debtor has settled the owed amount.

68 Quittance from Joannis Goyheche to Georges de Lasson le jeune, 16 Sept. 1705, LAC, MG1-G3, 7/175, pièce 48.

69 Declaration by Pierre Sugnet, 29 Oct. 1680, LAC, MG6-A17, procédure 6B, vol. 1009.

70 Mémoire des négociants de Saint-Jean-de-Luz et de Ciboure concernant la découverte de l'île de Terre-Neuve et l'origine des pêcheries des baleines et des morues, Mar. 1710, LAC, MG1-C11C, vol. 7, fol. 3-8.

71 Nicolas Landry, "Les Basques dans le golfe du Saint-Laurent se racontent," Acadiensis 37, 2 (2008): 117.

72 Réflexions des négociants de Saint-Jean-de-Luz et de Ciboure auprès de la Cour, Dec. 1716, LAC, MG1-C11C, vol. 7, f. 8-10.

73 Loewen and Delmas, "The Basques in the Gulf," 384.

74 Beauvais Lefer to the Minister, 28 Sept. 1727, LAC, MG2-B3, vol. 319. 
75 We may also cite the example of the Irish, who were particularly mistrusted by the English in the winter of 1697, in the context of the French raids along the English coast of Newfoundland. Father Beaudoin, who chronicled the exploits of d'Iberville, mentions the Irish Catholic engagés at Conception Bay. Some 30 Irish even deserted to join the French. See John Mannion, “... Notoriously disaffected to the Government: British allegations of Irish disloyalty in eighteenth-century Newfoundland," Nerwfoundland and Labrador Studies 16, 1 (2000): 1 .

76 See http://www.bac-lac.gc.cal. Fonds de l'Amirauté de Guyenne, Entrées et sorties, navigation, Archives départementales de la Gironde, Bordeaux. This site is within that of Library and Archives Canada.

77 All those references are available on the website.

78 The Aigle, property of Billates Frères, "bourgeois et marchands" of Bordeaux, undertook a busy itinerary in May 1698. It was to transport merchandise to Plaisance, Canada, the Îles d'Amérique, Cayenne, the Île de la Tortue, and Saint-Domingue. Four ships in our sample declared a cargo of stones for Plaisance: the Hirondelle, the Jacques, the Saint-Jacques, and the Sainte-Croix. 